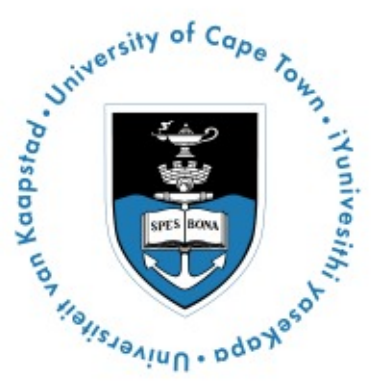

\title{
Reflections on the Nature of Policing and its Development
}

\author{
Clifford Shearing \\ Griffith University \\ University of Cape Town \\ University of Montreal
}

The Version of Record of this manuscript has been published and is available in Police Practice and Research (2015):

http://www.tandfonline.com/10.1080/15614263.2015.1109390. 
The following establishes a new occasional section in Police Practice and Research under the heading "Reflections". I am very pleased to initiate these "Reflections" with an "Oration" by Clifford Shearing presented at the Second International Conference on Public Health and Law Enforcement in Amsterdam in September 2014. A response to Shearing's presentation is provided by Scott Burris, a public health lawyer.

Dilip Das

Editor-in-Chief

\section{Reflections on the Nature of Policing and its Development ${ }^{1}$}

\section{Clifford Shearing}

Universities of Cape Town, Griffith and Montreal

\section{Introduction}

What I have been asked to do today is to reflect, with you, upon the nature of policing and its development.

I will do so by relating two stories. The first is a story about the processes by and through which safety is actually produced.

The second is an aspirational story about how safety should be produced. As with many aspirational stories, this second story has captured imaginations, and, in doing so, has shaped the way policing has been understood.

\footnotetext{
${ }^{1}$ Many thanks to Francisca Zimmermann for her assistance in the preparation of the oration and this paper.

The Version of Record of this manuscript has been published and is available in Police Practice and Research (2015): http://www.tandfonline.com/10.1080/15614263.2015.1109390.
} 


\section{Safety as Security}

Both my stories share a common understanding of policing. Namely, that the activities that we have come to reference as "policing" are activities intended to produce interpersonal safety.

Safety is an enormously valuable commodity, because, as the $17^{\text {th }}$ Century political philosopher Thomas Hobbes (1951) so clearly understood, its presence constitutes a "foundational order" upon which all social life depends. Interpersonal safety - that is freedom from what one might think of as hitting and taking harms, which we call "crime" - is one of several foundational orders, that include, for example, the ecological services that we as humans depend upon for our well-being. As Jared Diamond, in his wonderful book Collapse (2005), made so frighteningly clear, our civilizations require, for their existence and survival, the presence of an exacting set of ecological conditions. Without these conditions, human civilizations collapse.

Diamond's point - that a favourable set of ecological conditions constitutes a foundational ecological order - mirrors Hobbes' equally compelling observations about the foundational order of interpersonal peace. Without safety, both as a present condition, and as a future expectation, life, in Hobbes' pithy phrase, is destined to become "solitary, nasty, brutish and short" (Hobbes, 1951, p. 186).

Hobbes' term "peace" has increasingly given way, particularly over the past several decades, to the phrase "safety and security", or more simply to the word "security" as a way of referencing Hobbes' foundational interpersonal order. This contemporary usage has moved the term "security" out of its previously near exclusive context of "national security", and has accorded it with a much broader set of meanings - for example, "human security" (Brundtland, 1987).

The Version of Record of this manuscript has been published and is available in Police Practice and Research (2015): http://www.tandfonline.com/10.1080/15614263.2015.1109390. 
With these remarks in mind, let me now turn to the terms "police" and "policing".

Historically, the English verb "to police" was used to reference a wide range of activities. Today, the meaning of "to police", along with the meaning of the gerund "policing", have become closely coupled to the activities of police officers. This has created a linguistic gap that has been filled by the verb "to secure" and the noun "security" - a term that, as I have noted, is often coupled with "safety".

These shifts in meaning have shaped our vision, and with it, our understanding of the field of policing. This shaping, and reshaping, has brought non-state auspices and providers of security, and their activities, closer to the centre of our conceptual stages. This has, in the words of the sociologist Dorothy Smith, provided for new "ways of seeing" (Smith, 1987).

Among criminologists there have been two principal responses to these developments. On the one hand there have been scholars who have sought to incorporate these new meanings within our existing lexicon. The late Jean-Paul Brodeur sought to do this with the phrase, "the policing web" (Brodeur, 2010).

On the other hand there are scholars who have concluded that it is strategically better to accept the narrowing of meaning that has taken place with respect to the terms "police" and "policing" and to look for new terms that recognize a broader policing field within which police are located as one provider of security among others. As a consequence, today, a number of scholars (such as Kerr, 2015; Martin, 2013; Wood \& Shearing, 2007) have begun using terms such as "nodal security governance", "the governance of security", "security nodes", and very recently, "safety and security web" (Council for Canadian Academies, 2014), as a way of recognizing and recapturing these broader, and older, meanings. In commenting on this broader field of security governance, scholars have used terms such as "a quiet revolution" (Shearing \& Stenning, 1981) and "multilateralisation" (Bayley \& Shearing, 
2001) to identify, and trace, contemporary developments within the "governance of security".

At the forefront of this research on the nodal governance of security has been a focus on private security, which, until relatively recently, constituted an elephant in the security room. Today private security occupies a significant space within the security governance landscape, both locally and globally (Abrahamsen \& Williams, 2011). Quantitative estimates of just one set, and arguably the least significant set of agents, within the field of private security, namely private security guards, has revealed that in many parts of the world these private agents significantly outnumber police officers. Further, studies of commercial private security, where security guards are most numerous, indicate that the size and scope of its businesses is enormous. To provide a quick sense of the size and significance of private security globally, the Canadian political scientists Abrahamsen and Williams, in their 2011 book Security Beyond the State, noted that G4S - the world's largest security company - is present in over 110 countries, has 585,000 employees and is the biggest employer listed on the London stock exchange (Abrahamsen \& Williams, 2011, p. 41). In an earlier 2009 publication on "global security assemblages" Abrahamsen and Williams note that, in the United States alone, private security companies employed between 1.5 and 2 million persons, and that they outnumbered police by 3 to 1 (Abrahamsen \& Williams, 2009, p. 2). In addition to highlighting the growth of private security, this nodal story has also drawn attention to the plethora of other security players from the public, private and civil sectors. Consequently this nodal story is drawing an increasingly complex picture of security governance.

An important empirical feature of this nodal security picture has been that the public sector, and particularly the police, have not only maintained a firm foothold within security governance, but have been actively engaged in developing security assemblages across all sectors. The most obvious example of this has been the emergence of "community policing" - which the 1999 Patten Commission report on

The Version of Record of this manuscript has been published and is available in Police Practice and Research (2015):

http://www.tandfonline.com/10.1080/15614263.2015.1109390. 
policing in Northern Ireland termed "policing with the community" - as a significant feature of contemporary policing (Independent Commission on Policing for Northern Ireland, 1999, p. 40-45).

What this emerging nodal story of security governance makes clear is that, although police no longer dominate across "protection networks", ${ }^{2}$ they continue to be very significant role players within many areas of these networks but they do not dominate security governance in the way a Hobbesian inspired vision has hoped. Security governance has long been, and remains today, fundamentally polycentric.

The tendency by many scholars and practitioners, especially during the $20^{\text {th }}$ Century, to treat the field of security governance as if it were simply a police field has seriously limited theoretical understandings at both descriptive and explanatory levels and has led to crucial rethinking at the normative level.

As we learn more about nodal security it is becoming increasingly apparent that these "security assemblages", rather than producing a single comprehensive level of security as Hobbes had hoped, in fact have produced a varied multiplicity of "bubbles" (Bottoms \& Wiles, 1995) and "quilts" (Ericson, 1994) and "patchworks" (Zedner, 2009) of security that my colleague Philip Stenning and I (1983) some time ago dubbed as a "new feudalism" of "mass private property". An obvious example of these bubbles of security is the security enclaves of "gated communities" - Caldeira's (1996) "fortified enclaves" - which most of us partake of, in one way or another, as we go about our daily lives. Central to these account has been the argument that within nodal networks security is delivery as - in the British criminologists Tim Hope (2000) and Adam Crawford's (1998) words - a "club good" rather than a "public good". As a club good, security is delivered in ways that makes it available, in varying degrees, to some, but not all (see also Bayley \& Shearing, 1996).

\footnotetext{
${ }^{2}$ I am grateful to Mark Shaw for this felicitous phrase. The Version of Record of this manuscript has been published and is available in Police Practice and Research (2015): http://www.tandfonline.com/10.1080/15614263.2015.1109390.
} 
In the language of the late $19^{\text {th }}$ Century British historian, Frederic William Maitland (1885), nodal security systems produce a multiplicity of "private peaces" rather than a single "public peace". What Hobbes and Maitland, along with many others, had hoped for was a much more centralised system of security governance that would produce a single "public good".

As my references to Hobbes make clear, this is a compelling and inspiring dream. But this is not what has happened. And, given the nature of $21^{\text {st }}$ Century developments with respect to rising inequality (Piketty, 2014), this seems unlikely to happen any time soon. The normative argument that flows from this nodal understanding, as David Bayley and I noted in 1996, is that greater security equality within nodal systems requires interventions that shift the power relationships, which have created these inequalities, rather than simply making "rights" - based demands, no matter how strident, for greater equality (Bayley \& Shearing, 1996 - for a more recent discussion see Ayling, Grabosky \& Shearing, 2009).

The dominant response to these normative issues has been to recognize the nodal nature of security governance, and then to call for a neo-Hobbesian solution that seeks to "civilize" - to use lan Loader and Neil Walker's (2007) term - by firmly anchoring systems of nodal security governance within state governance. Given its resonance with long-established Hobbesian aspirations, this has been viewed by many as a very attractive option as it, in theory at least, enables policing, broadly conceived, to be brought under the control of established mechanisms of democratic accountability. This approach often seeks to deal with inequality through the strengthening of the capacity and reach of state agents in ways that allow the "swallowing up" of private peaces by a single public peace (Maitland, 1885).

A different but complementary approach (Bayley \& Shearing, 1996) has been to propose that attention be paid to possibilities for redressing some of the power differentials that underlie the inequalities of security delivery, which have given rise to the current security landscape, marked by differential levels of access to unequal

The Version of Record of this manuscript has been published and is available in Police Practice and Research (2015):

http://www.tandfonline.com/10.1080/15614263.2015.1109390. 
bubbles of security (Froestad \& Shearing, 2013). This approach considers the possibility of responding to inequalities of security governance by enhancing the capacities (Sampson's (2006) "collective efficacy") of weaker nodes to improve the quality of the bubbles of security to which they have access.

These approaches - the more state centred and the more nodal centred - constitute two parallel, and complementary, normative tracks, and have been proceeding apace. Both have been picked up, in one way or another, in recent policy reports on the state of security governance and how it might be improved. Examples include the Patten Report on security governance in Northern Ireland, published in 1999; the Dutch "Police in Evolution" report (Project Group Vision on Policing, 2006); the very recent 2013 British Steven's Report on the future of policing in England and Wales (Independent Police Commission, 2013); and the recently released Canadian Report on the future of policing (Council for Canadian Academies, 2014).

I will devote the remainder of my remarks to the second, nodally-focused approach by considering a set of design principles for enhancing the "methods of power" - to use the Australian regulatory scholar John Braithwaite's (2004) useful phrase - of vulnerable populations to enhance the quality of their security governance. In doing so I will draw, in particular, upon the work that I have been engaged in, in several countries, with colleagues like Monique Marks and Jennifer Wood (Marks, Shearing \& Wood, 2009; Shearing \& Wood, 2003). Some of this work, like recent work I have undertaken in South Africa with Julie Berg (Berg \& Shearing, 2011), has been focused on what governments, as landlords, can do to reshape the quality of safety within the bubbles of security to which vulnerable populations have access. An example, here, would be how governments, as landlord, can enhance the safety of vulnerable children in public schools through what the American criminologist John Eck has termed "place management" (Eck \& Wartell, 1996; Eck, 1994). Much of this nodallyfocused work, however, has focused on the capacities of the vulnerable populations themselves and how they can use their own capacities, as well as the capacities of others that they can enrol, as methods of power to enhance their levels of security.

The Version of Record of this manuscript has been published and is available in Police Practice and Research (2015):

http://www.tandfonline.com/10.1080/15614263.2015.1109390. 
John Braithwaite (2004), in work focused on vulnerable countries rather than vulnerable populations, has termed these methods of power the "weapons of the weak". Braithwaite's argument, following Foucault's line that power "comes from everywhere" (Foucault 1990, p. 93), is that, while the weak may not have many weapons at their disposal, drawing on the weapons they do have is a useful way of "nudging" change (Thaler \& Sunstein, 2008).

A few years ago, in a book entitled Imagining Security (2007), Jennifer Wood and I looked back over the body of work that we, and others, had undertaken to document efforts within a number of poor communities to reimagine their security by developing "methods of power" that recognized, and took advantage of, their "weapons" in the "nodal wars" (Shearing \& Johnston, 2010) in which they had been engaged. We conceived of these methods of power as constituting design principles that reflected, and promoted, the development of "sensibilities" (Shearing \& Ericson, 1991), which recognized, and embraced, possibilities for enhancing security within the context of contemporary security governance realities. I would like to draw this oration to a close by briefly referring to three of the six design principles that Jennifer and I articulated - with much borrowing from Braithwaite.

\section{Design Principles}

Design Principle 1: Concentrate power nodally and use it to steer Governance

This principle references the fact that poor and vulnerable communities in fact often have access to many resources that can be directed towards enhancing their security. The power of these resources to enhance their security is all too often not utilized because it is not concentrated and pooled. Simply rectifying this can significantly advance the security of these populations by creating mini versions of

The Version of Record of this manuscript has been published and is available in Police Practice and Research (2015):

http://www.tandfonline.com/10.1080/15614263.2015.1109390. 
what Foucault termed "power assemblages" (see for a discussion O'Malley, 2004 and Rose, 1999), and that Drahos has termed "superstructural nodes" (2004).

Within my own normative work in South Africa, the pooling of local knowledge and capacity through the establishment of "peace committees" allowed some 250 local communities to engage directly in using their own capacity and knowledge to address a wide range of insecurities (Froestad \& Shearing, 2013). During 2009, before funding for these Peace Committees was terminated for partisan reasons as a consequence of a change of government at the national level, Peace Committees had mobilized and concentrated the local knowledge and capacity in their communities to resolve over 40, 000 insecurities.

\section{Design Principle 2: Recognize and use all of your Power Resources}

This principle argues for the use of a wide-angle lens, rather than a telephoto lens, in seeking out resources. It recognizes that, all too often, resources that are available are neglected because they are not recognised.

This principle draws upon Latour's (1986) insight, as he sought to expand upon Foucault's understanding of power, that our ability to govern - that is, to shape the flow of events (Parker \& Braithwaite, 2003) - comes not from one's own resources but from one's ability to recognize and enrol the resources of others. Enrolment allows actors, whose own resources are limited, to punch way above their weight. A good example of this principle operating in a different context is the way in which FIFA, a player in an international context with relatively limited resources, repeatedly has been able to mobilise, and more importantly direct, the resources of other players, including governments of host countries, to realise its very specific, and often partisan, security governance objectives (Nakueira, 2014).

Another example comes from work I undertook, with others, in Toronto to document and support the efforts of residents of public housing estates to enhance

The Version of Record of this manuscript has been published and is available in Police Practice and Research (2015):

http://www.tandfonline.com/10.1080/15614263.2015.1109390. 
their security. At the heart of the successes that these residents enjoyed in turning around their security was their ability to mobilize and integrate a series of resources that they had not previously recognized as "security" resources. One example, among many, was the enrolment of fragile grannies to play card games in the foyers of multi-story buildings and in doing so to discourage drug dealers from using these spaces as sites for their business transactions. In doing so, these elderly residents transformed what had previously been bubbles of insecurity into bubbles of security.

\section{Design Principle 3: Focus on Nodes where one can be creative and assertive}

Many of the nodal players within security governance networks have very firmly established modus operandi that are difficult to shift. As the work of the great ethnographers of police work, like the American sociologist Egon Bittner (1967, 1990a, 1990b) and the British-Dutch police scholar Maurice Punch (2009) point out, established police practices are very resilient. This means that, while it is useful to turn to a node like the police in seeking assistance with one's security when their modus operandi fits with one's objectives, it is often better to start elsewhere if one's aim is to reshape one's security terrain. This is in fact precisely what powerful actors like businesses have done in turning to private security for assistance. This is also what the mentioned vulnerable communities in South Africa and Canada did as they sought to reshape their security.

\section{Conclusion}

Nodal policing is here to stay. The aspirational hope of a monopoly of policing by police constitutes an important feature of the history of policing, but it is unlikely to be an aspiration that can continue to inspire police in the way it has for several centuries. For police today, a key question facing them is: Who should police be within a polycentric world? This question of roles within nodal policing arrangements is not simply a question for police - it is a question that all those engaged in nodal policing face.

The Version of Record of this manuscript has been published and is available in Police Practice and Research (2015):

http://www.tandfonline.com/10.1080/15614263.2015.1109390. 
A second key question is: How should nodal policing arrangements be managed and by whom? This is most certainly a question that governments are, and should be, grappling with. However, once again, this is not simply a question for governments, but is a question for all those who are engaged in nodal policing arrangements.

The answers to these questions will be produced within the countless crucibles of practice that define nodal policing. The answers that emerge will do much to shape the capacity of policing arrangements to respond to the security challenges of the $21^{\text {st }}$ Century. These challenges promise to be quite different to the ones that shaped the $20^{\text {th }}$ Century.

\section{Response}

\section{Scott Burris}

Temple University, and the Robert Wood Johnson Foundation's Public Health Law Research Program

In many places, far too many places, Hobbes' war of all against all persists as reality, not metaphor. Insecurity is enacted everywhere and at every level, from the family to whole regions of the globe. Setting aside war and civil war, confining our discussion to the realms of public order within the management capacity of police still leaves a roster of ills and injuries- physical and psychic, immediate and chronic to deal with (Burris, 2006).

Policing needs to enlist public health sectors, because it is clear that in many places police cannot manage violence, mental illness, substance abuse and profound social alienation alone. The traditional tools of criminal law and police management cannot prevent these ills, determined as they are by a flood of upstream risk factors that overwhelms the dykes downstream. The intergenerational and viral nature of 
violence also comes into play - highlighting the needs for treatment that are essential to future prevention, breaking the cycle.

But health, like security, has become nodal (Burris, 2004; Burris, Drahos \& Shearing, 2005). In health we now speak of health systems, complex assemblages of public and private treatment and prevention. Like the police, health systems face the imperative to involve the community in meaningful ways, and to share some of their power. Health workers, like police, cannot rely simply on hospitals and prevention programs targeted at particular diseases to create an optimal level and distribution of health. We understand from 30 years of social epidemiology, which in turn goes back in social science at least as far as Durkheim, that health unfolds across a lifetime of interaction of the organism with its particular social and physical environment (Burris, Kawachi, \& Sarat, 2002; Burris, 2011). The essential attribute of a healthy environment for our purposes can come down to just exactly what Hobbes, and Shearing in his Oration, were talking about: "We say that we are safe and secure, and that we feel safe and secure, when we share a confident expectation about safety both now and in the future."

In both health and policing, we spend a lot of time dealing with the immediate consequences of human frailty amid usually less than safe and secure environments. We work to prevent and treat the diseases that manifest the life course and environment in the body, and the crimes that express it in harmful behaviour. That's a good and important focus of work - as long as we and most of those we are working for are living in a reasonably safe and secure environment. But once that ceases to be true - when too many are living in insecurity - that model of proximate action frays: in part, because, typically, the more insecure the environment generally the fewer the human and material resources are available for health and policing, but more fundamentally because there is some tipping point at which the flow of illness and crime from upstream cannot be staunched by downstream tactics. 
We face the same insufficiencies in our two fields: we cannot make places of deep inequality safe or healthy. We cannot keep the lives of the desperate, alienated, unemployed and unhoused peaceful and orderly. We cannot - nor should we-make the world safe for exploitation, injustice and inequality. Ultimately, the bubbles of security Clifford spoke of must burst, and either security or insecurity spread and prevail.

This is a shared task. What makes interdisciplinary work succeed is not the wholesale adoption by one of the relevant disciplines of the attitudes and practices of the other, though I think we can do better by sharing information, harmonizing data and cooperating both tactically on the street and strategically in building new models of work. What we need is a shared understanding of the problems we face and of the goal of our efforts. Shearing's Oration has captured that shared understanding and aim, what motivates us deeply to come together. We must be in the business of using the resources and tools at our disposal to promote in every way we can policies and practices that truly acknowledge and seek to address the fundamental problem of security inequality that damages or threatens every one of our countries.

How do we do that? Clifford Shearing told two stories - of peace committees and tenants groups - that illustrated both the practical advantages of a nodal approach for dealing with inequality in security, and an ethical course for people like us, solving day-to-day problems in a context of severe or rising inequality. That's where my story comes in.

Many people who have become interested in the health-security link have done so because of their involvement in harm reduction. "Harm reduction" has been a powerful example of how an idea can coordinate the actions of diverse actors across extended networks (Marlatt, Larimer, \& Witkiewitz, 2012). All over the world, the simple idea of meeting drug users and other legally ostracized people where they are, and starting with their humanity and autonomy, proved to be astoundingly powerful: morally attractive, practical to implement, and soon backed by evidence of 
effectiveness, it spread rapidly and then developed in a decentralized, yet synchronized, way. It has also been an excellent example of how the weak - drug users, sex workers, and other legally marginalized people and their supporters - can use the design principles Clifford described to change settled practices and re-align power relations.

First, it worked nodally. Every syringe exchange or safe injection room or sex worker collective was a node, a little organization within which knowledge and capacity and resources could accumulate and then be projected out as power across networks (Biradavolu et al., 2009). The two people who started our syringe exchange program (SEP) in Philadelphia could not have been further from any conventional idea of power, a drug user and an unemployed artist, members of Act Up. But organizing, as they knew, allowed them to network with politicians, lawyers, community leaders, consumers, and in short order they were working with the mayor and the health commissioner and the police.

And this reflected, too, the second principle, to use the power one has. No one else had any idea how to stop HIV among drug users. This technology of harm reduction was power. The fact that the SEP was networked with drug users also, paradoxically, turned out to be a source of power. When a flood of fentanyl-tainted heroin hit the city, the Drug Enforcement Administration came to the SEP for help.

And, finally, harm reduction exemplifies the value of superstructural nodes. Both in academia and in the NGO sector, nodes were born to focus on harm reduction strategies among IDUs and sex workers. These groups - and I won't mention any to avoid offence to the many I cannot mention - did research, tracked progress, advocated, lobbied, pushed legislation and for international acceptance at places like the WHO, UNAIDS and the Commission on Narcotic Drugs. The local power of thousands of nodes was concentrated and reinforced by the work of these specialist nodes, just as Shearing advises.

The Version of Record of this manuscript has been published and is available in Police Practice and Research (2015):

http://www.tandfonline.com/10.1080/15614263.2015.1109390. 
The story of harm reduction shows that the weak can win. And let's remember that in the ranks of government, health and police are in the relatively weak side in many places. But the story also has an ethical dimension. It is daunting to think of one's mission as fighting fundamental social inequality. Earlier I used the metaphor of "upstream" risk factors. Clifford Shearing might call that misleading. He does not place the structural, social sources of insecurity far away. He sees that inequality and insecurity are enacted and reinforced every day in people's lives and communities. His story of Peace Committees, and my story of harm reduction, both show us a way to envision and pursue fundamental change in the macro-environment by working in specific communities in smart ways. In the Peace Committee Model he and his colleagues developed, a sophisticated approach to restoring a confidence in future security was built into a simple system that busy people in South Africa's poorest townships could own and use to resolve thousands of small disputes before they grew into dangerous ones. Harm reduction, using the most basic health tools and services, with the right mentality, has literally proven capable of stopping HIV and - I submit - changing the whole conversation about drug policy.

People like Clifford Shearing in policing and harm reductionists in health present both a practical and ethical model for our common task of reversing the inequality in human security. They do not for a moment accept the status quo, and have a profound understanding of how inequality is produced and enforced, but they commit to devote part of their efforts always to taking it on in concrete work in specific places. People working at the intersection of health and security are in an ideal position to emulate people like these. We can take the vision of security equality into the communities where we work. In practical terms, some part of our day, some part of what we do, must focus beyond the immediate and make some progress towards creating the social, political and economic infrastructure of security for all. I am certain that the discussions growing around law enforcement and public health will generate a range of ideas for how to do that.

\section{References}

The Version of Record of this manuscript has been published and is available in Police Practice and Research (2015):

http://www.tandfonline.com/10.1080/15614263.2015.1109390. 
Abrahamsen, R., \& Williams, M. C. (2009). Security Beyond the State: Global Security Assemblages in International Politics. International Political Sociology, 3, 1-17. doi: https://dx.doi.org/10.1111/j.1749-5687.2008.00060.x.

Abrahamsen, R., \& Williams, M. C. (2011). Security Beyond the State: Private Security in International Politics. Cambridge: Cambridge University Press.

Ayling, J., Grabosky, P., \& Shearing, C. (2009). Lengthening the Arm of the Law: Enhancing Police Resources in the Twenty-first Century. Cambridge: Cambridge University Press.

Bayley, D. H., \& Shearing, C. (1996). The Future of Policing. Law \& Society Review, $30(3), 585-606$.

Bayley, D. H., \& Shearing, C. (2001). The New Structure of Policing: Description, Conceptualization, and Research Agenda. Washington, DC: National Institute of Justice.

Berg, J., \& Shearing, C. (2011). The Practice of Crime Prevention: Design Principles for More Effective Security Governance. SA Crime Quarterly, 36, 23-30.

Biradavolu, M. R., Burris, S., George, A., Jena, A., \& Blankenship, K. M. (2009). Can Sex Workers Regulate Police? Learning from an HIV Prevention Project for Sex Workers in Southern India. Social Science \& Medicine, 68(8), 1541-1547. doi: https://dx.doi.org/10.1016/j.socscimed.2009.01.040.

Bittner, E. (1967). Police Discretion in Emergency Apprehension of Mentally III Persons. Social Problems, 14(3), 278-292.

Bittner, E. (1990a). Florence Nightingale in Pursuit of Willie Sutton: A Theory of the Police. In E. Bittner, Aspects of Police Work (pp. 233-268). Boston: Northeastern University Press.

Bittner, E. (1990b). Urban Police. In E. Bittner, Aspects of Police Work (pp. 18-29). Boston: Northeastern University Press. The Version of Record of this manuscript has been published and is available in Police Practice and Research (2015): http://www.tandfonline.com/10.1080/15614263.2015.1109390. 
Bottoms, A., \& Wiles, P. (1995). Crime and Insecurity in the City. In C. Fijnaut, J. Goethals, T. Peters, \& L. Walgrave (Eds.), Changes in Society, Crime and Criminal Justice in Europe (pp. 1.1-1.10). Leuven: Kluwer.

Braithwaite, J. (2004). Methods of Power for Development: Weapons of the Weak, Weapons of the Strong. Michigan Journal of International Law, 26(1), 297-330.

Brodeur, J. P. (2010). The Policing Web. Oxford: Oxford University Press.

Brundtland, G. H. (1987). Our Common Future: The World Commission on Environment and Development. Oxford: Oxford University Press.

Burris, S. (2004). Governance, Microgovernance and Health. Temple Law Review, 77(2), 335-358.

Burris, S. (2006). From Security to Health. In J. Wood \& B. Dupont (Eds.), Democracy and the Governance of Security (pp. 196-216). Cambridge: Cambridge University Press.

Burris, S. (2011). From Health Care Law to the Social Determinants of Health: A Public Health Law Research Perspective. University of Pennsylvania Law Review, 159(6), 1649-1667.

Burris, S., Drahos, P., \& Shearing, C. (2005). Nodal Governance. Australian Journal of Legal Philosophy, 30, 1-30.

Burris, S., Kawachi, I., \& Sarat, A. (2002). Integrating Law and Social Epidemiology. Journal of Law, Medicine \& Ethics, 30, 510-521. doi: https://dx.doi.org/ 10.1111/j.1748-720X.2002.tb00422.x.

Caldeira, T. (1996). Fortified Enclaves: The New Urban Segregation. Public Culture, 8, 303-328.

Council for Canadian Academies. (2014). Policing Canada in the 21st Century: New Policing for New Challenges. Ottawa: Council of Canadian Academies.

The Version of Record of this manuscript has been published and is available in Police Practice and Research (2015):

http://www.tandfonline.com/10.1080/15614263.2015.1109390. 
Crawford, A. (1998). Community Safety and the Quest for Security: Holding back the Dynamics of Social Exclusion. Policy Studies, 19(3-4), 237-253. doi: https://dx.doi.org/10.1080/01442879808423759.

Diamond, J. (2005). Collapse: How Societies Choose to Fail or Succeed. New York: Penguin.

Drahos, P. (2004). Intellectual Property and Pharmaceutical Markets: A Nodal Governance Approach. Temple Law Review, 77, 401-424.

Eck, J. E. (1994). Drug Markets and Drug Places: A Case-Control Study of the Spacial Structure of Illicit Drug Dealing (Ph.D. dissertation), University of Maryland, College Park, MD.

Eck, J. E., \& Wartell, J. (1996). Reducing Crime and Drug Dealing by Improving Place Management: A Randomized Experiment. Report to the San Diego Police Department. Washington D.C: Crime Control Institute.

Ericson, R. (1994). The Division of Expert Knowledge in Policing and Security. British Journal of Sociology, 45(2), 149-175.

Foucault, M. (1990). The History of Sexuality, Volume 1: An Introduction. New York: Vintage Books.

Froestad, J., \& Shearing, C. (2013). Security Governance, Policing, and Local Capacity. Boca Raton: CRC Press.

Hobbes, T. (1951). Leviathan. (C. B. Macpherson, Ed.). London: Penguin.

Hope, T. (2000). Inequality and the Clubbing of Private Security. In J. B. Armstrong, S. H. Edwards, H. B. Roberson, \& R. Y. Williams (Eds.), Teaching the American Civil Rights Movement: Freedom's Bittersweet Song (p. 83-106). Oxon and New York: Routledge.

The Version of Record of this manuscript has been published and is available in Police Practice and Research (2015):

http://www.tandfonline.com/10.1080/15614263.2015.1109390. 
Independent Commission on Policing for Northern Ireland. (1999). A New Beginning: Policing in Northern Ireland. Belfast: Stationery Office.

Independent Police Commission. (2013). Policing for a better Britain. London: Independent Police Commission.

Kerr, J. (2015). Securitization and Policing of Art Theft: The Case of London. London: Ashgate.

Latour, B. (1986). The Powers of Association. In J. Law (Eds.), Power, Action, and Belief: A New Sociology of Knowledge? (pp. 264-280). London: Routledge \& Kegan Paul.

Loader, I., \& Walker, N. (2007). Civilizing Security. Cambridge: Cambridge University Press.

Maitland, F. (1885). Justice and Police. London: Macmillan \& Co.

Marks, M., Shearing, C., \& Wood, J. (2009). Who should the police be? Finding a new Narrative for Community Policing in South Africa. Police Practice and Research: An International Journal, 10(2), 145-155. doi: https://dx.doi.org/10.1080/15614260802264560.

Marlatt, G., Larimer, M., \& Witkiewitz, K. (2012). Harm Reduction : Pragmatic Strategies for Managing High-Risk Behaviors (2nd ed.). New York: Guilford Press.

Martin, J. (2013). Informal Security Nodes and Force Capital. Polcing and Society: An Internationa Journal of Research and Policy, 23(2): 145-163. doi: https://dx.doi.org/10.1080/10439463.2012.671821.

Nakueira, S. (2014). New Architectures of Governance: Transnational Private Actors, Enrolment Strategies and the Security Governance of Sports Mega Events (Ph.D. dissertation), University of Cape Town, South Africa.

The Version of Record of this manuscript has been published and is available in Police Practice and Research (2015): http://www.tandfonline.com/10.1080/15614263.2015.1109390. 
O'Malley, P. (2004). Risk, Uncertainty and Government. London: The Glasshouse Press.

Parker, C., \& Braithwaite, J. (2003). Regulation. In P. Cane \& M. Tushnet (Eds.), The Oxford Handbook for Legal Studies (pp. 119-145). Oxford: Oxford University Press.

Piketty, T. (2014). Capital in the Twenty-First Century. Cambridge, MA: Harvard University Press.

Project Group Vision on Policing. (2006). Police in Evolution. The Hague: Board of Chief Commissioners.

Punch, M. (2009). Police Corruption: Deviance, Accountability and Reform in Policing. Cullompton: Willan Publishing.

Rose, N. (1999). The Powers of Freedom: Reframing Political Thought. Cambridge: Cambridge University Press.

Sampson, R. (2006). Collective Efficacy Theory: Lessons Learned and Directions for Future Inquiry. In F. Cullen, J. Wright, \& K. Blevins (Eds.), Taking Stock: The Status of Criminological Theory (pp. 149-168). New Brunswick, NJ: Transaction Publishers.

Shearing, C., \& Ericson, R. (1991). Culture as Figurative Action. The British Journal of Sociology, 42(4), 481-506.

Shearing, C., \& Johnston, L. (2010). Nodal wars and network fallacies: A genealogical analysis of global insecurities. Theoretical Criminology, 14, 495-614. doi: https://dx.doi.org/ 10.1177/1362480610378828.

Shearing, C., \& Stenning, P. (1981). Modern Private Security: Its Growth and Implications. Crime and Justice, 3, 193-245.

The Version of Record of this manuscript has been published and is available in Police Practice and Research (2015):

http://www.tandfonline.com/10.1080/15614263.2015.1109390. 
Shearing, C., \& Stenning, P. (1983). Private Security: Implications for Social Control. Social Problems, 30(5), 493-506.

Shearing, C., \& Wood, J. (2003). Nodal Governance, Democracy, and the New “Denizens." Journal of Law and Society, 30(3), 400-419. doi: https://dx.doi.org/10.1111/1467-6478.00263.

Smith, D. E. (1987). The Everyday World As Problematic: A Feminist Sociology. Boston: Northeastern University Press.

Thaler, R., \& Sunstein, C. (2008). Nudge: Improving Decisions about Health, Wealth, and Happiness. New Haven, CT: Yale University Press.

Wood, J., \& Shearing, C. (2007). Imagining Security. London: Willan.

Zedner, L. (2009). Security. New York: Routledge.

The Version of Record of this manuscript has been published and is available in Police Practice and Research (2015):

http://www.tandfonline.com/10.1080/15614263.2015.1109390. 